\title{
A new subspecies of the genus Leptoconops from Amami-oshima, Japan (Ceratopogonidae: Diptera)
}

\author{
Hiroyuki TAKAOKA* and Yoshihiro HAYASHI** \\ * Department of Medical Zoology, Faculty of Medicine, Kagoshima \\ University, Usuki-cho, Kagoshima 890, Japan \\ ** The Amami Laboratory of Medical Zoology, The Institute of Medical \\ Science, The University of Tokyo, Setouchi-cho, Oshima-gun, Kagoshima \\ 894-15, Japan
}

(Received: August 8, 1977)

\begin{abstract}
A new subspecies of the biting midge, Leptoconops (L.) nipponensis oshimaensis is described based on the female specimens collected from Amami-oshima Island, Japan. This is differentiated from the type species, L. (L.) nipponensis Tokunaga, 1937 by the different value of antennal ratio, the longer bristle-like setae on vertex and on prescutellar area of the thorax and the stoutness of the spines on the basitarsus of fore leg.
\end{abstract}

Following complaints of biting midge infestations from residents of Katoku and Isu villages on sandy coast of the southern part of the Amami-oshima Island, collections were made on April 15 and 17, 1977, to identify the causative species and to obtain basic information relevant to the control measures.

Examinations of the female specimens collected on human-bait from Katoku village have showed that this species belongs to the genus Leptoconops and has a close resemblance to $L$. (L.) nipponensis Tokunaga which is so far the only species of the genus from Japan and has been reported to be distributed in the south-west area of Honshu, main Island (Tokunaga, 1937; Nagahana et al., 1959 ; Ishigami, 1959).

To confirm the identification of this species we made a comparison with the 14 female specimens from Yonago, the type locality of $L$. nipponensis in addition to the original- and re-descriptions given by Tokunaga (1937) and by Chanthawanich and Delfinado (1967).

* 高岡宏行：鹿児島大学医学部医動物学教室（干 890 鹿児島市宇宿町 1208-1)

***林良博：東京大学医科学研究所奄美病㕩動物

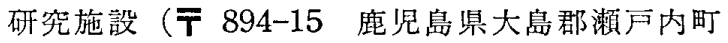
手安須手)
As a result, it was revealed that this species was almost identical to $L$. nipponensis except that a few features were constantly different. Therefore, we consider and describe this species as a new subspecies of L. nipponensis.

\section{DESCRIPTION}

\section{Leptoconops (Leptoconops) nipponensis oshimaensis sp. nov.}

Female : Body length $2.0 \mathrm{~mm}$. Wing (from arculus to wing tip) $1.15 \mathrm{~mm}$ long and $0.52 \mathrm{~mm}$ wide.

Head: Blackish brown, $0.30 \mathrm{~mm}$ high and $0.34 \mathrm{~mm}$ wide. Vertex with 4 bristle-like setae in the middle between eyes as well as a few lateral ones (Fig. 2). Eyes bare, widely separated by distance equal to 6 facets $(0.08 \mathrm{~mm})$. Antenna (Fig. 7) dark brown, composed of scape, pedicel and 12 flagellar segments; 2nd and 3rd flagellomeres somewhat transverse, slightly shorter than breadth; 4 th and 5 th flagellar segments almost spherical and 6 th to 11 th ones shortly cylindrical, longer than wide; terminal segment elongate, about 3.6 times as long as its width and much shorter than 3 preceding segments together; antennal segments in 


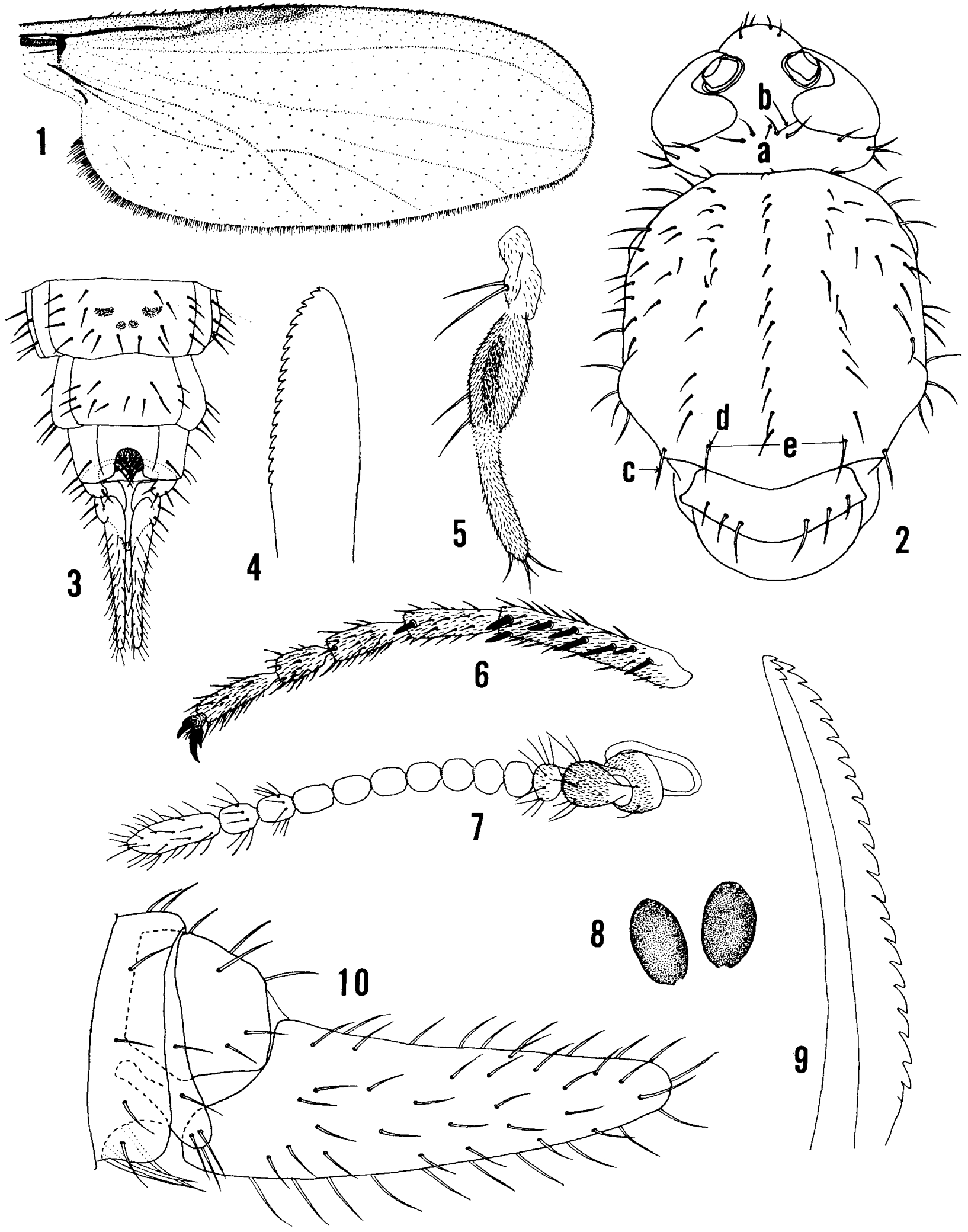

Figs. 1-10 Female of L. oshimaensis

1. Wing, 2. Dorsal view of head and thorax, a. Frontal seta on vertex, b. Distance from the base of frontal seta to the nearest of the eye margin, c. Supra-alar seta, d. Dorsomedian seta, e. Distance between dorso-median setae, 3. Ventral view of distal segment of abdomen, 4. Mandible, 5. Maxillary palp, 6. Tarsal segments of fore leg, 7. Antenna (hairs on 3rd to 9th flagellar segments are omitted), 8. Spermathecae, 9. Galea, 10. Lateral view of cercus 
proportion of $7: 12: 5: 5: 6: 6: 6.5: 7: 7:$ $7.5: 7.5: 7.5: 18$ (scape not measured). Mouth part about $1 / 2$ length of head, with 14 setae on labella. Mandible (Fig. 4) with about 20 distinct teeth. Galea (Fig. 9) with a few inner teeth and about 20 outer teeth. Maxillary palpus mostly brown, 3rd segment, darkest of all and base of 4 th segment completely pale; 3 rd segment slightly swollen, with large sensory area occupying almost entire length of inner margin and with about 5 long setae (Fig. 5); length in proportions of $7: 7: 17: 20$.

Thorax: Brownish black, shiny ; mesonotum with 3 longitudinal rows of setae on dorsal surface and with scattered setae on each side ; scutellum with 6 marginal bristlelike setae; postscutellum bare (Fig. 2).

Wing: Dirty white, oval in shape, with dark marking covering distal portion of radial cell (Fig. 1) ; $R s$ ending at middle of costal margin.

Legs: Dark brown, with tips of tibiae and tarsal segments paler; basitarsi of all legs with 5-10 stout spines in addition to one pair of apical ones (Fig. 6); 2nd tarsal segment of fore leg with only one apical spine, those of middle and hind legs with one pair of apical spines; tarsal claws symmetrical, each with a medium-sized basal tooth, being about $1 / 2$ length of main tooth; proportional lengths from femur to 5 th tarsal segment $25: 24: 10: 5: 4: 2: 5$ in fore leg $; 30: 26: 11: 6: 4: 2: 4$ in middle leg; and $32: 30: 15: 10: 5: 3: 5$ in hind leg.

Abdomen: Mainly brown, the apical segments darker; 2 nd and 3 rd tergites bare except a few setae on either lateral portion; 4 th to 7 th tergites also almost bare with a few to several setae on lateral and posterior margins; lateral pleural membrane bare; 2nd sternite bare; $3 \mathrm{rd}$ to 7 th sternites with several setae along lateral and posterior margins and a few setae medially; 3 rd to 6 th sternites each with 4 spots shaped as in Fig. 3 on which microtrichia is absent; cerci elongate caudad (about $1.0 \mathrm{~mm}$ ) nearly 2.5 times as long as its basal broadest portion (Fig. 10) ; spermathecae 2 in number, well sclerotized, oval and equal $(0.05 \mathrm{~mm} \times 0.04$ $\mathrm{mm}$ ) (Fig. 8).
Locality: Amami-oshima, the Amami Islands, Japan.

Holotype: Alcoholic female, collected by Mr. Y. Noboru, from Katoku, Setouchi-cho, Oshima-gun, Kagoshima Pref., on April 4, 1977.

Paratypes: Twenty alcoholic females, same data and locality as holotype.

Specimens for reference: L. n. nipponensis females -6 specimens from Yonago, Tottori Pref., collected by Prof. M. Nagahana, in 1960, and sent through Dr. S. Kitaoka, and 8 specimens, same locality, collected and sent to us by Prof. M. Nagahana, July, 1977. Types will be deposited in the National Science Museum in Tokyo.

Remarks: According to the original- and re-descriptions by Tokunaga (1937) and by Chanthawanich and Delfinado (1967), this new subspecies is easily differentiated from the type subspecies, L. nipponensis nipponensis which was described to have a pair of apical spines on 2 nd tarsal segment of fore leg and the ultimate segment of the antenna as long as the 3 preceding segments put together. However, all the 14 specimens of $L$. n. nipponensis from the type locality have been found to have a single apical spine on 2 nd tarsal segment of fore leg instead of 2 spines. It therefore seems that this feature can not be used reliably in identification of the relevant species. On the other hand, the value of antennal ratio appears to be considerably constant. In L. n. oshimaensis the terminal segment of the antenna is much shorter than the 3 preceding segments together (total length of the 3 preceding segments/terminal segment $=0.82 \pm 0.05$ (mean \pm standard deviation), range $=0.73-0.89, n=$ 12 ), whereas in $L . n$. nipponensis the value of this ratio is $0.96 \pm 0.04$ (range $=0.92-1.00$, $n=4$ ), that is, the terminal segment of the type species is nearly as long as the 3 preceding segments together as mentioned by the previous authors. Apart from this difference, this subspecies is separable from $L$. $n$. nipponensis by the following features. The frontal setae of 4 setae in the middle on vertex are much longer than the distance from their bases to the nearest of the eye margin in $L$. $n$. oshimaensis $(a / b=1.85 \pm 0.23$, range $=1.63-2.25, n=8$ ). However, those of 
L. n. nipponensis are almost equal in length to the distance from their bases to eye margin $(a / b=0.93 \pm 0.02$, range $=0.75-1.13, n=$ 10). Similarly, the relative lengths of some setae on dorsum of the thorax which are indicated in Fig. 2 may be used in identifying these subspecies. The dorso-median setae $(d)$ on prescutellar area of the present subspecies are almost $1 / 2$ as long as the distance between them $(e)(e / d=2.07 \pm 0.13$, range $=1.85-2.27, n=8)$ and are nearly equal in length to the supra-alar setae $(c)$ on caudolateral corners of the scutum $(c / d=1.00 \pm$ 0.08 , range $=0.9-1.1, n=8$ ). In L. n. nipponensis, the values of $e / d$ and $c / d$ were $4.25 \pm 0.26$ (range $=3.82-5.00, n=8$ ) and 1.70 \pm 0.03 (range $=1.55-2.00, n=6$ ), respectively. Namely, the length of setae $d$ of $L$. n. nipponensis is about $1 / 4$ the inter-setal distance (e). Furthermore, although the spines except 2 apical ones on the basitarsus of fore leg of $L$. $n$. oshimaensis are variable in number (median $=7$, range $=5-10, n=10$ ) and overlap the range of $L$. $n$. nipponensis (median $=5$, range $=3-9, n=25$ ), at least, some of spines of $L$. $n$. oshimaensis are always the same as the larger spine of 2 apical ones in length and stoutness. On the contrary, those of $L$. n. nipponensis appear to be smaller or more slender than the larger one of 2 apical spines.

\section{ACKNOWLEDGEMENTS}

The authors wish to express their gratitudes to Prof. A. Sato, Faculty of Medicine, Kagoshima University, Kagoshima, for his valuable suggestion in preparing the manuscript.

Thanks are due to Prof. M. Nagahana, Kawasaki Medical University, Kurashiki, and Dr. S. Kitaoka, National Institute of Animal Health, Tokyo, for their kindness in supplying the valuable specimens of $L$. n. nipponensis.
The authors also wish to thank Prof. $\mathrm{H}$. Tanaka, and Mr. Y. Noboru, the Amami Laboratory of Medical Zoology, The Institute of Medical Science, The University of Tokyo, for their cooporation in the field surveys.

\section{REFERENCES}

Chanthawanich, N. and M. D. Delfinado (1967): Some species of Leptoconops of the Oriental and Pacific regions (Diptera, Ceratopogonidae). J. Med. Entomol., 4 (3) : 294-303.

Ishigami, K. (1959) : On morphology and ecology of the biting black gnat Leptoconops nipponensis Tokunaga (Ceratopogonidae). Yonago Igaku Zasshi, 10 (1) : 179-203.

Nagahana, M., K. Ishigami and H. Toyama (1959): On the geographical distribution of biting black gnat, Leptoconops nipponensis Tokunaga and on the human blood sucking habits of the species. Yonago Igaku Zasshi, 10 (1) : 207-208.

Tokunaga, M. (1937) : Sand flies (Ceratopogonidae, Diptera) from Japan. Tenthredo, 1 (3) : 233-338.

\section{摘要}

\section{奄美大島産 Leptoconops属 の新亜種について}

奄美大島南部の東海岸に位置する花徳部落において主 に春季の $3 ， 4$ 月にかけて発生し，人を激しく襲 5 吸血 昆虫の予備調查を 1977 年 4 月に行いトクナガクロヌカ 力 (Leptoconops nipponensis Tokunaga, 1937) に極め て類似した種の雌標本を人四法によって多数得た.

トクナガクロヌカカの原記載および再記載の他, トク ナガクロヌカカの基産地である鳥取県米子産の雌標本と の形態を比較した結果，本種は，現在比較が可能な雌成 虫に関してはトクナガクロヌカカとほとんど区別が困難 な程類似しているが，わずかに触角末端節とその前 3 節 を合せた長さの比，頭頂および胸背後縁上の 剛毛の長 さ，さらに前脚第一跗節の剛針の大きさに一定した差が 認められるので，本種をトクナガクロヌカカの新亜種と して報告する。 